\title{
BRCA1 Gene
}

National Cancer Institute

\section{Source}

National Cancer Institute. BRCA1 Gene. NCI Thesaurus. Code C17965.

This gene plays a role in cell cycle control, regulation of transcription and the

maintenance of genomic stability. It is also involved in the inhibition of mammary cell growth. 